\title{
PIPELESS DEVICE FOR WATER LIFTING THROUGH WELL CASING STRING
}

\section{VALERY ARTUROVICH TUMLERT, EVGENY VALEREVICH TUMLERT, TATYANA GRICHANAYA \& GULNAZ TELGARAEVA}

Professor, Kazakh Scientific Research Institute of Water Management, Taraz, Republic of Kazakhstan

\begin{abstract}
This article describes development of pipeless device for water lifting through well casing string. Intensive development of all sectors of national economy requires for increased water consumption. Water supplies from open sources in Kazakhstan are nearly exhausted, thus, now-a-days underground waters are intensively extracted. The developed pipeless device for water lifting provides fixation of submersible pumpsat preset depth in well; possibility of repositioning to higher depth; discharge of water column above the device during mounting works, which excludes swabbing; protection of sealing element against contact with casing string during tripping and possibility to flush sand deposits from packer due to its shape in transit and working positions, resistance against sand-off; maintainability of sealing element under field conditions; adjustment of maximum permissible working pressure on sealing element; manufacturability and unification of structural members of various form factors. Accompanying engineering equipment makes it possible to seal mouth well, to provide fixation and sealed inlet of electric pump cable into well, protection of the cable against deformation during mounting operations, to perform mounting and dismounting with serial machinery (mobile cranes, drilling rigs, tripods), that is, as close as possible to existing technology of mounting/dismounting with submersible pumps.
\end{abstract}

KEYWORDS: Pump, Well \& Device for water lifting through well casing string

Received: Mar 26, 2020; Accepted: Apr 16, 2020; Published: May 22, 2020; Paper Id.: IJMPERDJUN202064

\section{INTRODUCTION}

Well is the main supply source of underground waters. Operation of water supply wells with pump units, model ETsV has demonstrated that these pumps are reliable, they are mounted using water lifting pipes which support the pump at preset depth and water is supplied upwards using these pipes.

In fact, a string of water lifting pipes is lowered into casing string. Thus, each well is equipped with at least 30 to 150 meters of steel pipes with the diameter from 50 to $219 \mathrm{~mm}$. Such arrangement of water lifting equipment in a well creates difficulties during mounting/dismounting operations due to non-axiality of well shaft and water lift pipe string, it does not allow to provide sealed covering of mouth well and requires for high amount of pipes. Therefore, there are intensive investigations into possibilities to use casing string for supply of underground waters, which would decrease significantly metal intensity of water supply facilities. The efficiency of equipment for water evacuation through well casing string at one water supply well (at the cost of $1 \mathrm{t}$ of steel pipes equaling to 140 thousand tenge) would amount from 80 to 770 thousand tenge.

Development of agricultural water supply and pasture irrigation due to implementation of resource-saving technologies of pipeless water lifting, advanced hydrocyclone and other technologies improving specifications of water supply facilities is especially important during current stage of market development. 
Initial experiments with water lifting through well casing string were started in Design Bureau of the Ministry of Chemical Engineering of the USSR in 1954 for oil wells. Submersible pump with packer was hanged on rope and required for special design of pump electric motor. Despite successful experimental results, the electric pumps on ropes were not implemented commercially in oil industry due to restricted application in wells with abundant gas evolution, increased content of paraffin and mechanical impurities in evacuated fluid, unavailability of serial pumps with upper mounting of electric motor.

Intensive developments of equipment for pipeless mounting of submersible pumps, analysis and operation of such wells for water supply have been intensively carried out in recent 15-20 years.

At present various designs are known for water supply from wells through casing string. However, these designs are characterized by significant disadvantages: high axial loads during mounting, existence of special borings and supports in casing pipe, application of drill rods for mounting, etc., which prevents their extended implementation.

The equipment for pipeless mounting of submersible pump in well was developed by such enterprises as Soyuzgiprovodkhoz, TsNIIKIVR, KazNIIVKh, YuzhNIIGiM, BelKTIGKh, Remselburvod, as well as individual researchers.

\section{METHODS}

The device for water lifting through well casing string has been developed in TOO KazNIIVKh[1-4], thus:

- $\quad$ water lifting pipes are saved;

- pollution of water bearing bed is prevented;

- labor intensity during mounting/dismounting operations is reduced by $40-70 \%$;

- power consumption for water lifting is reduced by $30 \%$;

- the yield of water bearing bed increases, thus resulting in competitiveness of the proposed technology.

The use of casing string as water lifting facility assumes application of special device for pipeless water lifting. Using this device, a submersible pump is fixed at preset depth and separates the well shaft into suction and injection areas. Water is lifted through casing string and not through water lifting pipe applied upon conventional well operation.

This technology of underground water evacuation facilitates intensification of withdrawal of underground waters by means of vacuum creation in pump suction area. Therefore, important task of pipe saving and intensification of water withdrawal is solved.

The use of well casing string as water lifting pipes saves funding for acquisition of water lifting pipes and decreases operational costs, increases labor efficiency upon operation of water supply facilities, as well as improves sanitary epidemiological situation. Technical and economical performances of the device demonstrate reasonability of its application in implementation of innovation projects. At present, such devices are neither fabricated nor applied in Kazakhstan and CIS, competitive analogs for water evacuation through well casing string in terms of simplicity and reliability as well as readiness for commercial implementation are unavailable. 
An interesting operation feature of a well with pipeless mounting of submersible pump has a possibility to intensify underground water withdrawal by means of vacuum, that is, artificial gravity field allowing to withdraw not only free but also capillary water under the action of significantly higher hydraulic gradient in filtration flow of underground waters.

The device can be applied for facilities of municipal, industrial and agricultural water supply.

The most efficient embodiment of pipeless mounting of submersible pumps and water lifting through well casing string is achieved with submersible pumps, models ETsV 10, 12 with flowrate of at least $60 \mathrm{~m}^{3} / \mathrm{h}$ and up to $200 \mathrm{~m}^{3} / \mathrm{h}$.

In terms of maximum economic efficiency, the optimum installation depth of ETsV pump with the device is as follows:

- for medium-head (60-70 m) pumps: $20 \ldots 40 \mathrm{~m}$;

- for high-head (100 m and above) pumps: $40 \ldots 80 \mathrm{~m}$, which approximately equals to $1 / 3 \ldots 2 / 3$ of nominal heads of these pumps.

This approach could be implemented for agriculture (irrigation by underground waters, vertical drainage, irrigation of pastures); water supply of rural settlements; agro industrial companies.

At present, such devices are neither fabricated nor applied in Kazakhstan, competitive analogs for water evacuation through well casing string in terms of simplicity and reliability as well as readiness for commercial implementation are unavailable.

\section{RESULTS}

Figure 1 illustrates flowchart of water lifting through well casing string by means of submersible pump, model ETsV;Figs. 2, 3 show variants of devices for water evacuation in terms of mounting in well (mounting by means of rods or rope).

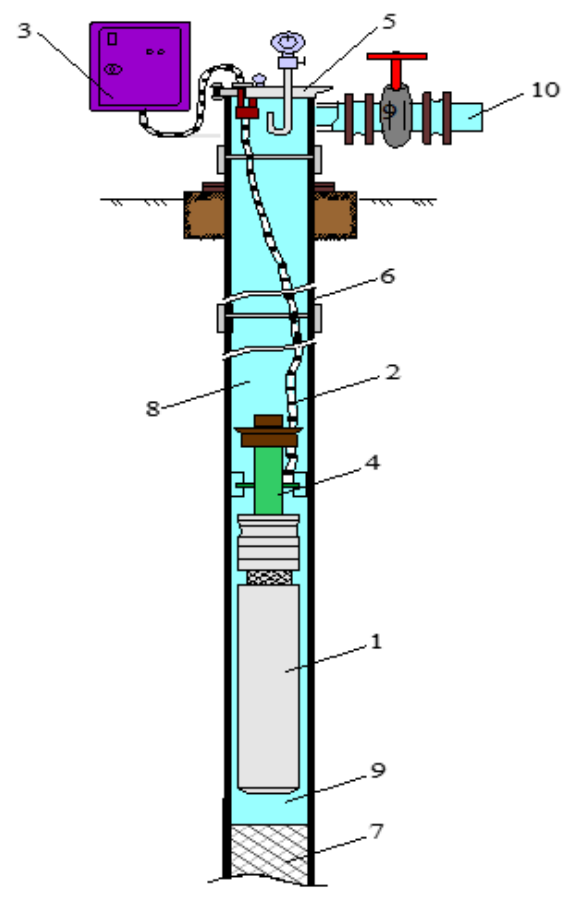


1: submersible pump;

2: electric cable;

3: control center;

4: pipeless device for water lifting;

5: sealed parapet;
6: casing string;

7: well filter;

8: injection area;

9: suction area;

10: to consumer.

Figure 1: Schematic View of Water Lifting through Well Casing String.

A set of equipment is comprised of the device for pipeless water lifting, sealed parapet of mouth well, mounting accessories.

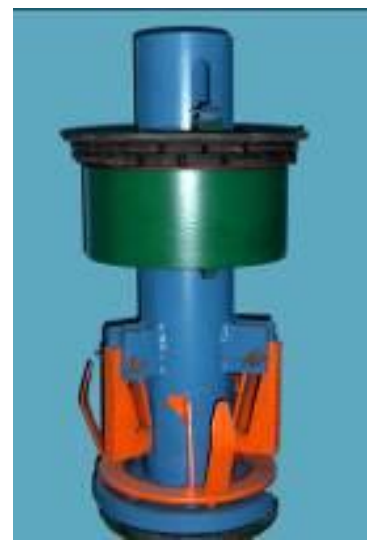

Figure 2: Pipeless Device for Water Lifting (Rod Mounted).

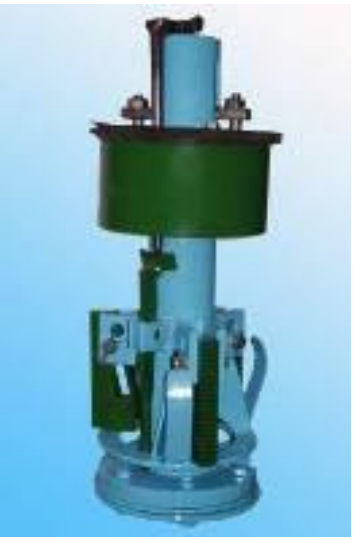

Figure 3: Pipeless Device for Water Lifting (Rope Mounted).

The body is comprised of steel pipe with rigidly fixed upper and lower flanges and U-shaped eyes, the pipe top has longitudinal slots. The body is used for installation of all attached elements of sealing unit and fixation mechanism, the body provides passage of fluid injected by pump via internal cavity and takes the vertical load of pump unit and fluid column in injection area.

Submersible pump is connected to the lower flange.

Using the mounting accessories, the submersible pump is lowered to preset depth and the device is fixed in well casing string. When sealing ring is opened, the casing string is separated into suction and injection areas. Then the accessories are disconnected and lifted. The mouth well is closed by sealing parapet (Figure 4). When the submersible 
pump is activated, water is pumped from the suction area to the injection area, then it is lifted through well casing string above and supplied to consumers. Submersible pump is dismounted in reverse order.

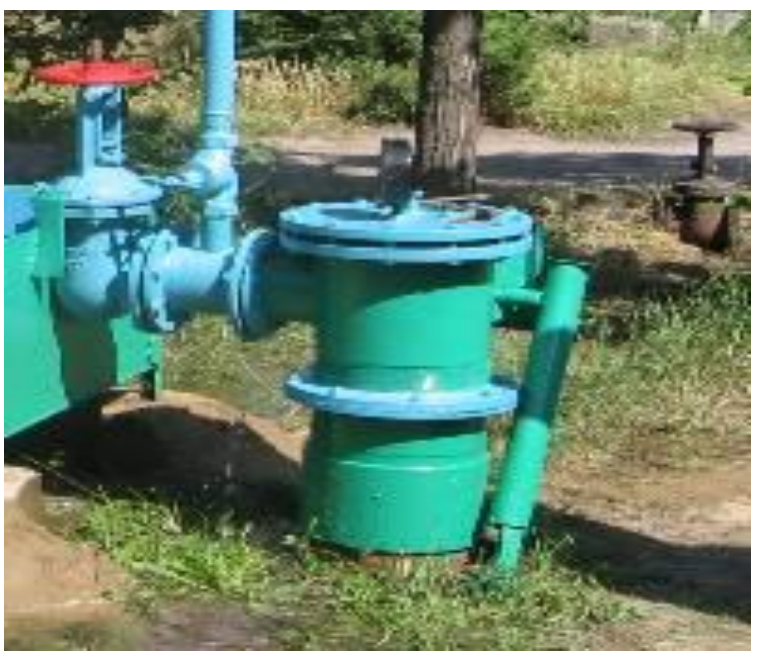

Figure 4: Water Supply Well Equipped for the New Technology.

The mounting sequence of equipment for evacuation of underground water through well casing stringis illustrated below.

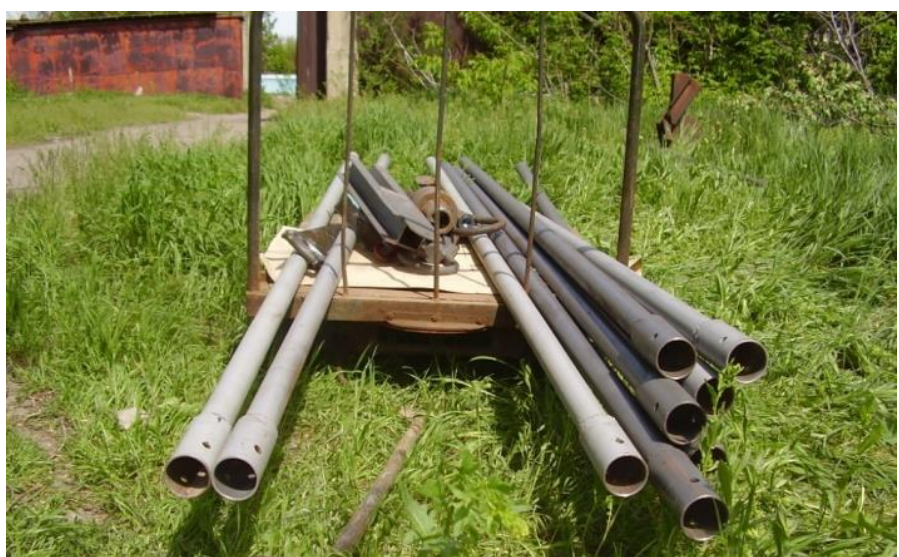

Figure 5: Accessories for Mounting and Dismounting of Device with Etsv Submersible Pump in Well.

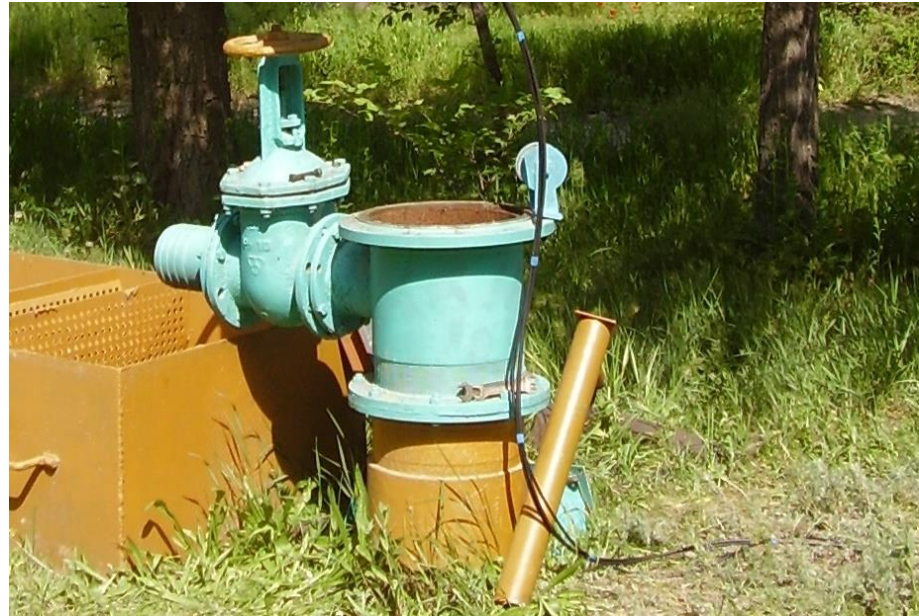

Figure 6: Arrangement of Sealed Well Parapet. 

Tatyana Grichanaya \& Gulnaz Telgaraeva

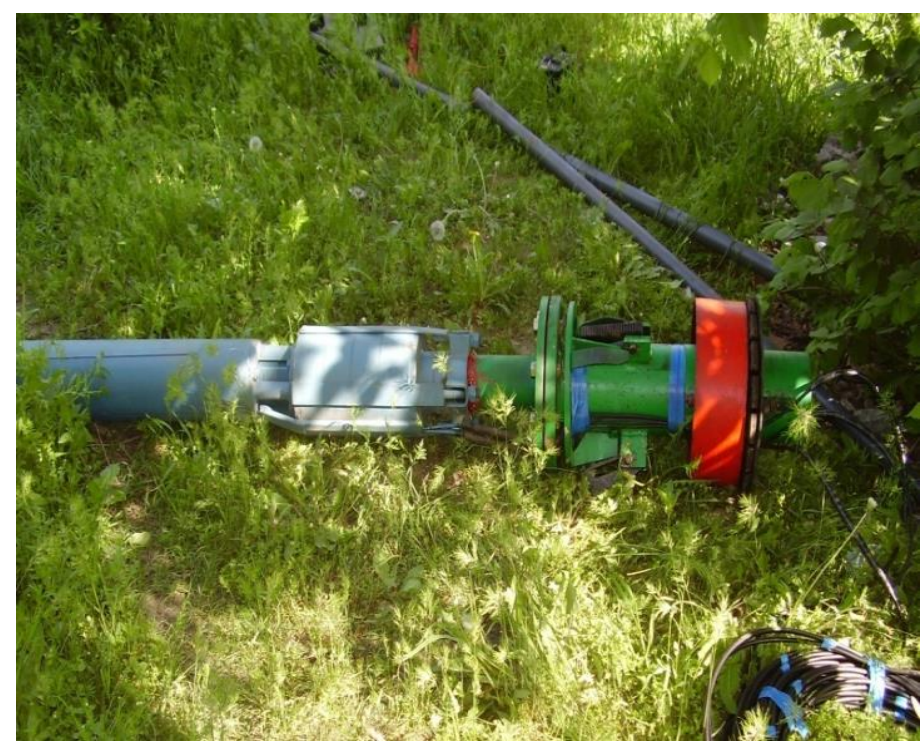

Figure 7: Connection of ETsVpump to Pump.

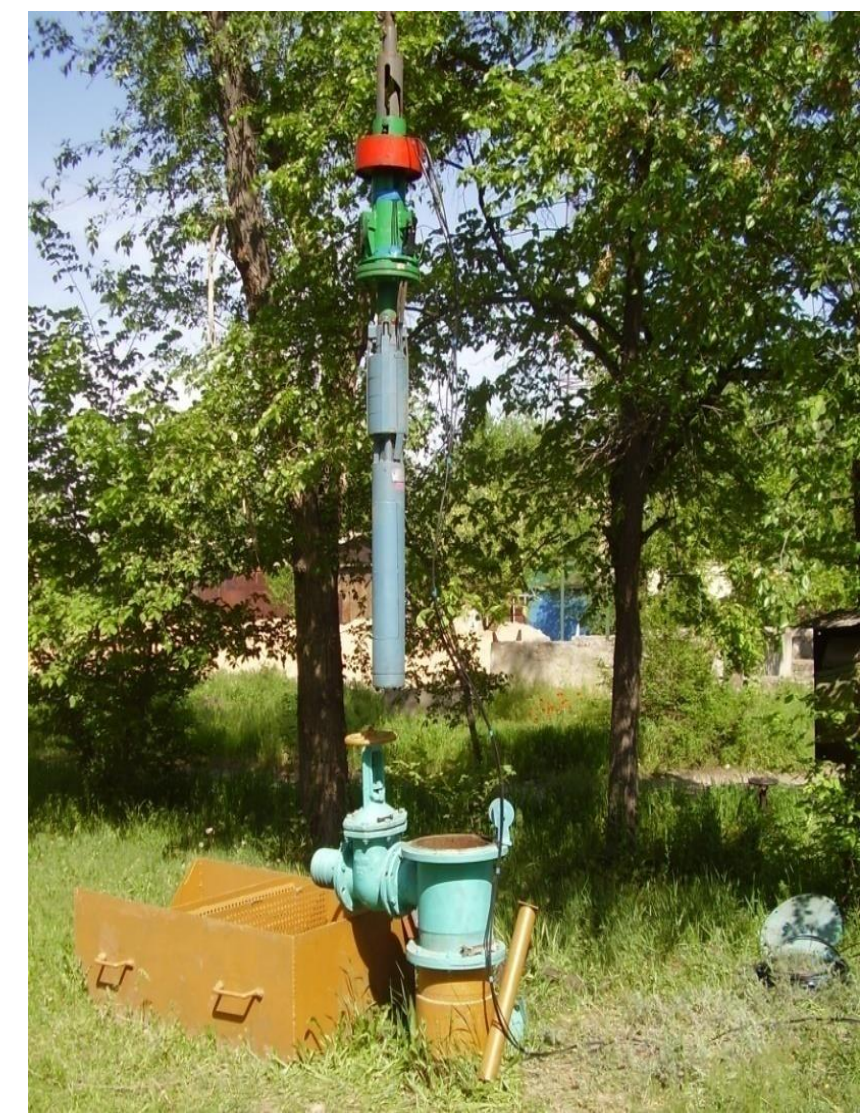

Figure 8: Suspension of Device with Pump above Well. 


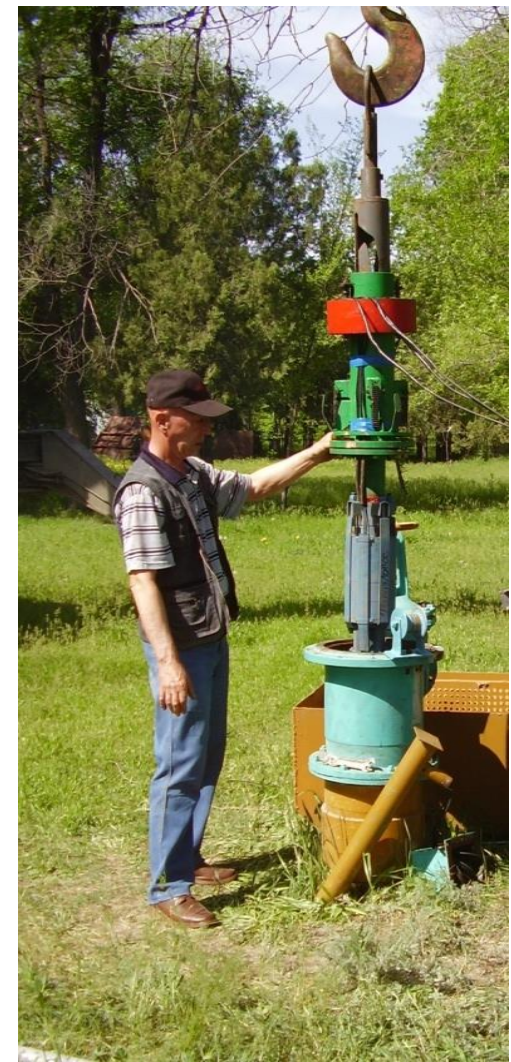

Figure 9: Lowering of Device with Pump into Well.

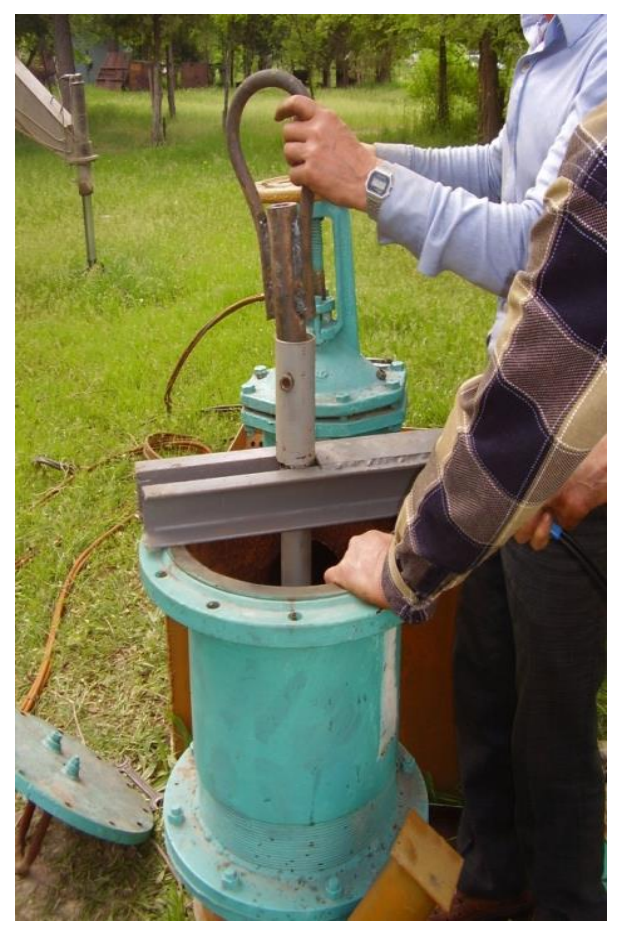

Figure 10: Fixation of Rod with Eye by Mounting Fork on Mouth Well upon Extension of Rod Length. 


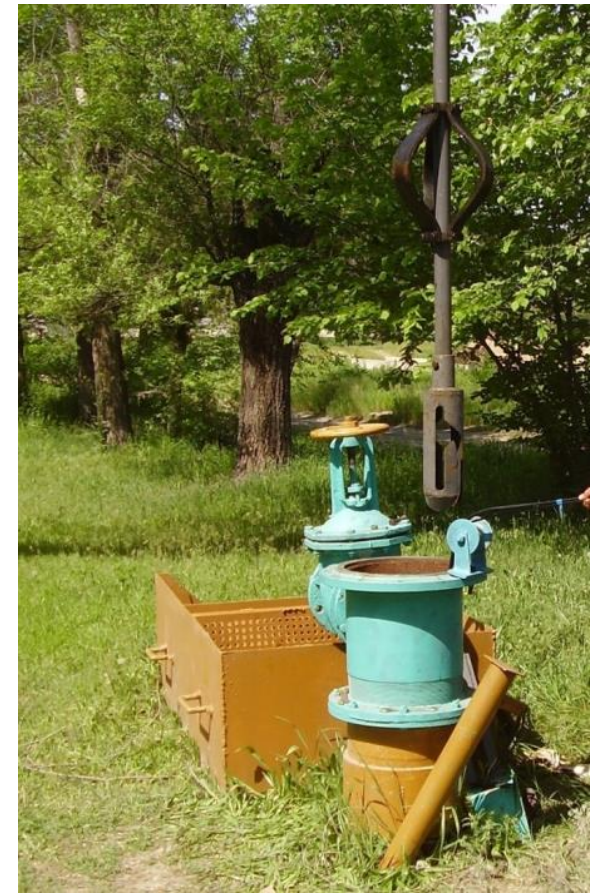

Figure 11: Mounting Accessories Extracted from Well After installation of the Device with Pump at Designed Depth.

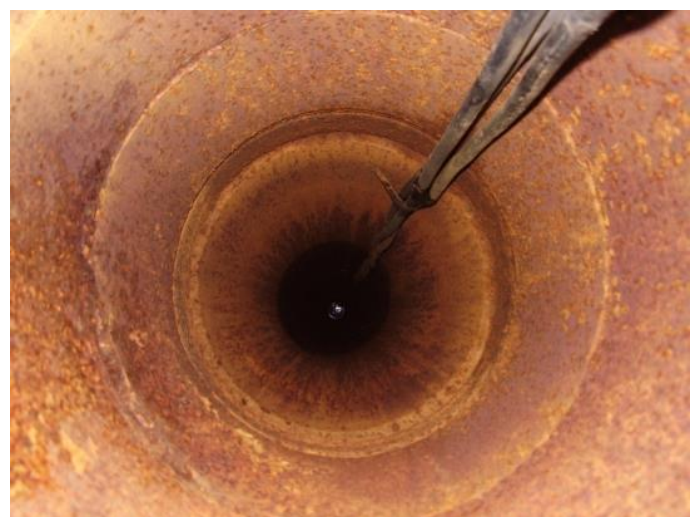

Figure 12: Internal Space of Casing String After Installation of Device with Pump.

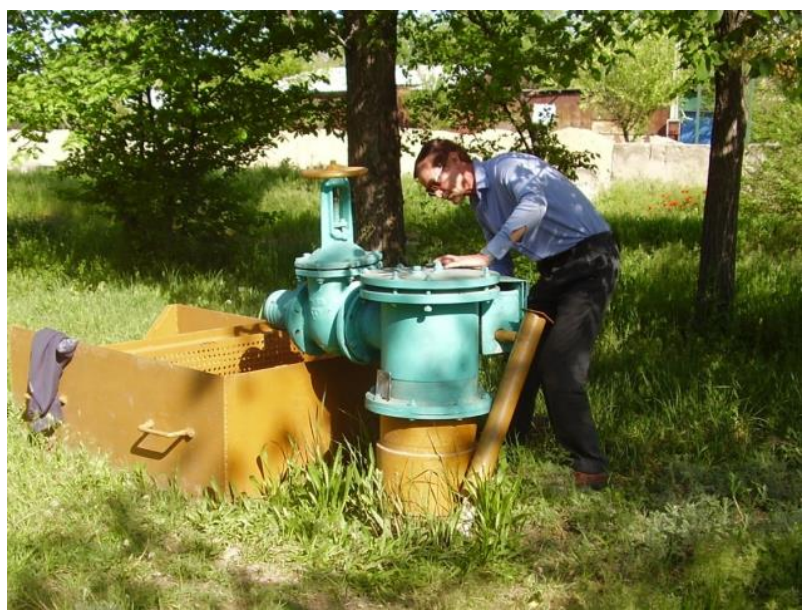

Figure 13: Sealing of Well Parapet. 


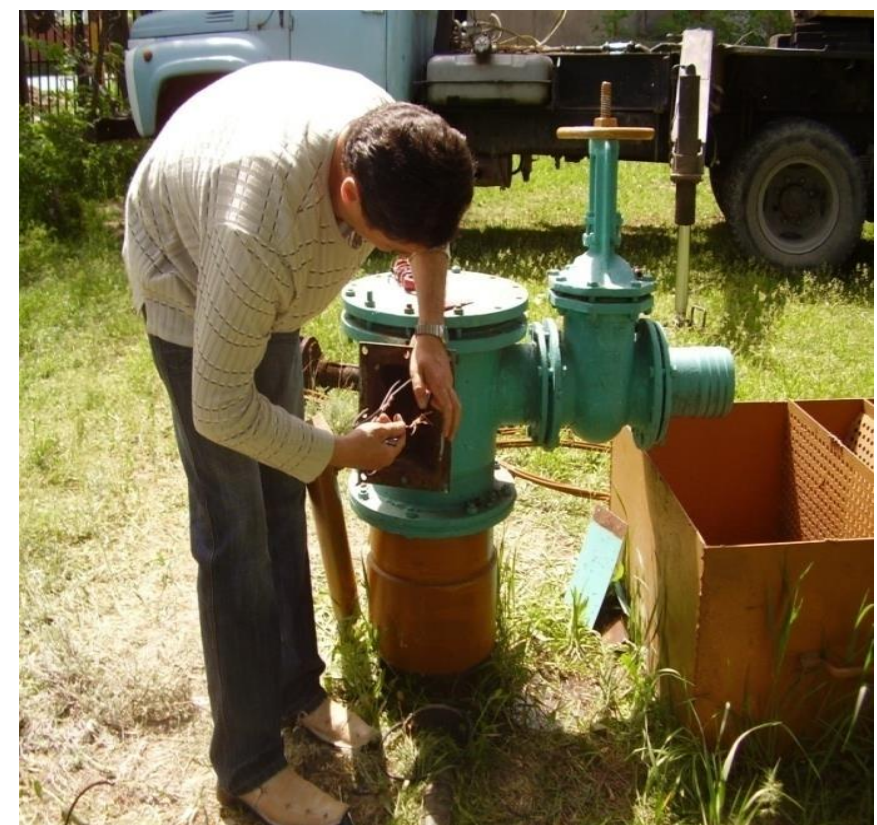

Figure 14: Connection of ETsVpump Cable to Power Supply.

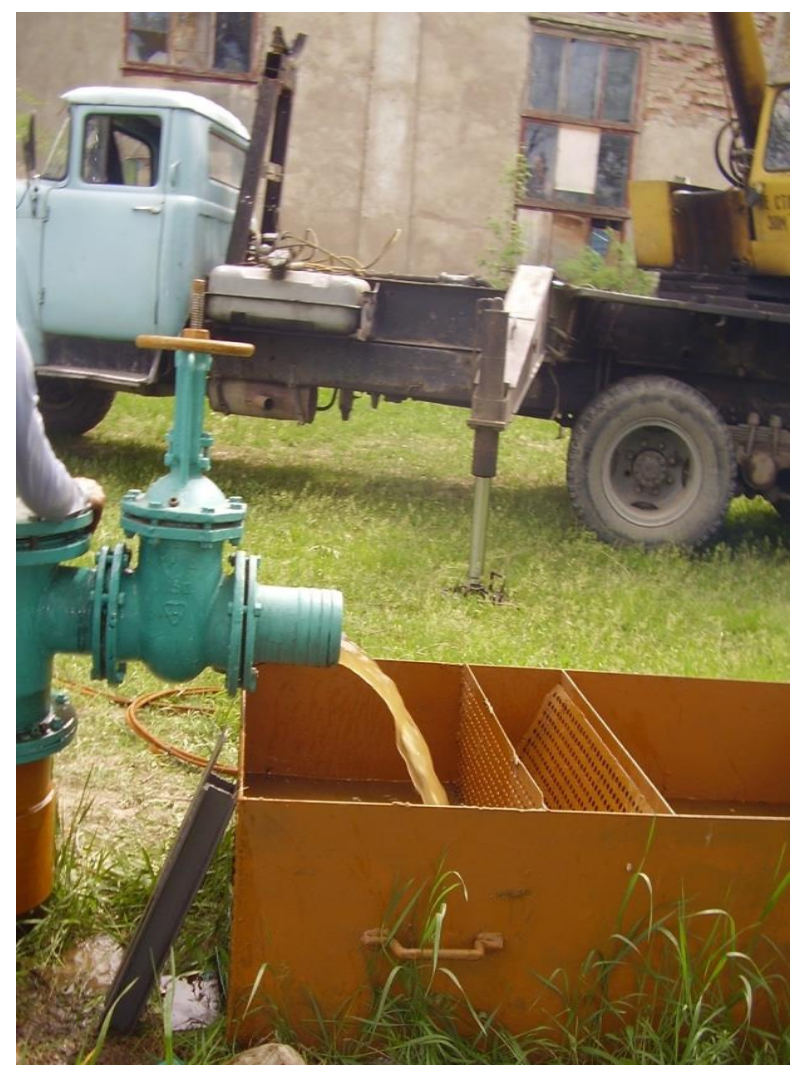

Figure 15: Water Evacuation from Well.

The embodiment in Figure 3 is lowered and lifted from well using rope, which eliminates application of specialized machinery (mobile crane, drilling rig) due to tripod with hoisting device (manual, electric) allowing to any farmer to perform mounting/dismounting. 
The equipment is protected by the USSR Author certificate No.1633864 and KZ patent No.22926.

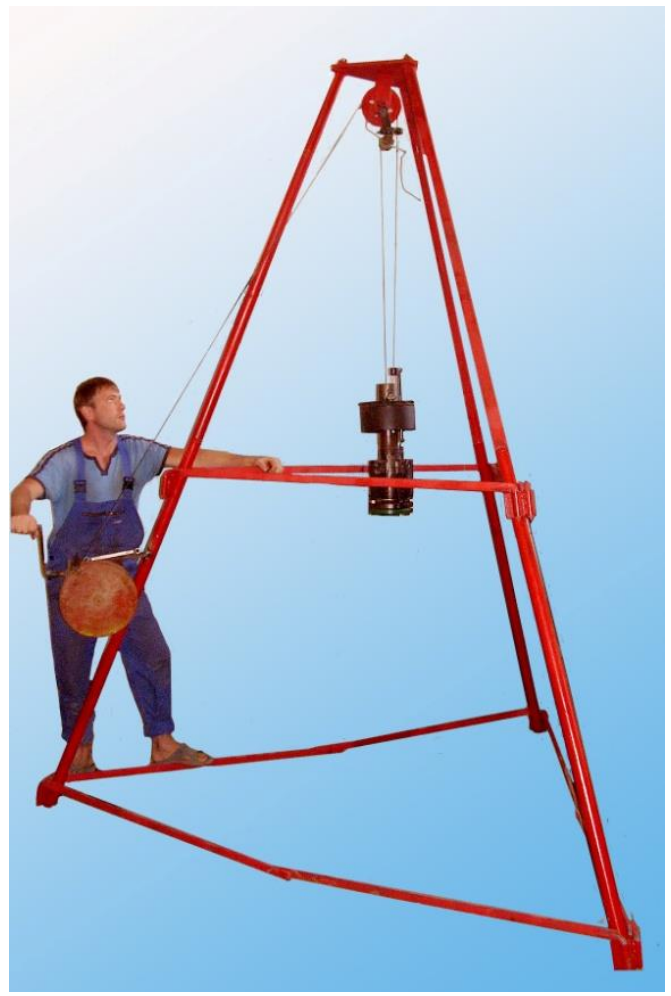

Figure 16: General View of the Accessories.

The owner of the intellectual property rights is Kazakh Scientific Research Institute of Water Economy.

Specification for equipment of underground water evacuation through well casing string $\varnothing \varnothing 219,273,324,377$, $426 \mathrm{~mm}$ was developed, including samples of actual embodiment for various typical well sizes and Operation manual for water supply wells with water evacuation through well casing string.

Pilot tests were performed with wide-scale approbation in most regions of Kazakhstan at wells of utility and drinking water supply, irrigation, vertical drainage, water depression.

The pilot technological equipment for underground water evacuation was approved by the solution of authorized commission.

Standard design TP RK 1-12VS SKV-2009 "Water supply facilities from underground sources with the productivity from 1 to $12 \mathrm{~m}^{3} / \mathrm{h}$ " was developed.

In order to select substantiated mode of pump operation in vacuum well, to estimate its stability, possible depression of underground waters and intensification of water withdrawal, combined operation of well and pump was analyzed during stationary and transient processes; hydraulic losses were determined in suction/injection areas as well as their constituents, critical rarefaction at pump input and in the bed; the optimum conditions and the field of application of pipeless water lifting from wells were formulated.

A well is considered as a complex system comprised of suction area, water lifting equipment, injection area. The suction area is comprised of hydraulic subsystems: water bed and well filter. Submersible pump is a combination of electromechanical (submersible electric motor) and hydromechanical (pump unit) subsystems. The injection area is 
comprised of pressure pipeline and return line, that is, hydraulic subsystems.

The main calculated dependences of water lifting system in stationary mode of pump operation are as follows:

$$
\begin{aligned}
& H=\left(H_{w}+S_{v}\right)+h_{\text {wpump }}+H_{c B}, \\
& H_{\text {wрump }}=h_{\text {fr:pump }}+\Sigma h_{\text {loc.pump }}, \\
& Q=f(H), \\
& S_{v}=S+h_{w}, \\
& S=Q R /(4 \pi K M) \\
& h_{w}=h_{f}+h_{f r}+\sum h_{l o c}+h_{p e r m}, \\
& h_{\text {suc }}<h_{\text {w.perm }}, \\
& h_{\text {suc }}=z_{\text {pump }}-H_{\text {perm }}, \\
& h_{\text {suc.perm }}=H_{a t}+h_{\text {d.liq. }}-\Delta h_{c r}-h_{w}, \\
& \Delta h_{c r}=f(Q) . \\
& H_{v}<H_{v . p e r m}, \\
& H_{v \cdot p e r m}=H_{a r} h_{f l u i d}-\Delta h_{c r}, \\
& H_{v}=h_{v}-\Delta H_{\text {pump }}-v^{2} /(2 g) .
\end{aligned}
$$

Where $Q$, Hare the predicted flow rate and head of pump; $S_{v}, S$ are the head drop in well and near well; $h_{w}, h_{f}, h_{f r}$, $h_{l o c}, h_{m}$ are the hydraulic losses in suction area, filter, dead end of casing string, local losses, and losses for flowing of pump motor; $h_{w i n j}, h_{f r . i n j}, h_{l o c . i n j}$ are the hydraulic losses in injection area for friction, for length, and local; $h_{i n j}, h_{i n j . p e r m}$ are the geometrical height of suction, calculated and permissible; $z_{\text {pump }}, H_{\text {head }}$ are the height of pump in well, head in well; $H_{v}$, $H_{v . p e r m}, h_{v}$ are the vacuum height of suction, calculated and permissible, vacuum under packer; $\Delta H_{\text {pump }}$ is the pump depth under level of fluid; $v^{2} /(2 g)$ is the flow strength at pump input.

In transitional mode of pump operation, Eqs. (1) ... (5) are rewritten as follows:

$$
\begin{aligned}
& H^{\prime}=H\left[1-\frac{\omega_{2}}{T_{2}} e^{-\theta_{2} t / T_{2}} \sin \left(\omega_{2} t+\operatorname{arctg} \frac{\omega_{2} T_{2}}{\theta_{2}}\right)\right], \\
& h_{\text {winj }}^{\prime}=h_{\text {winj }}+h_{\text {iner } 2}, \\
& h_{\text {iner } 2}=\frac{L_{H T} d Q^{\prime}}{g F d t} \\
& Q^{\prime}=Q\left[1-\frac{\omega_{1}}{T_{1}} e^{-\theta_{1} t / T_{1}} \sin \left(\omega_{1} t+\operatorname{arctq} \frac{\omega_{1} T_{1}}{\theta_{1}}\right)\right] \\
& S(r, t)=\frac{1}{4 \pi K M}\left(Q_{i}-Q_{i-1}\right) E\left(\frac{r^{2}}{4 a\left(t_{i}-t_{i-1}\right)}\right)
\end{aligned}
$$




$$
\begin{aligned}
& h_{\text {winj }}^{\prime}=h_{\text {winj }}+h_{\text {inerl }}, \\
& h_{\text {iner }{ }_{1}}=\left(\frac{L_{\text {Д }}}{F_{k g}}+\frac{L_{B T}}{F_{g}}\right) \cdot \frac{d Q^{\prime}}{d t}
\end{aligned}
$$

Where $H^{\prime}, Q$ are the pump head and flow rate; $h_{\text {inerl }}, h_{\text {iner } 2}$ are the inertia heads in suction/injection areas; $\omega, T$, $\theta$ are the angular frequency, time constant, coefficient of attenuation of transitional process; $t$ is the time from pump start.

The obtained dependences make it possible to determine hydraulic head near the well and in the well shaft at any time after activation of submersible pump, hydraulic losses and their constituents, as well as pressure gradients occurring upon pump operation in the well shaft and in the gravel pack.

Operation efficiency of water lifting equipment was estimated on the basis of the following conditions:

- cavitation-free operation of pump unit;

- minimum suffusion under washing of water bearing materials and well filter area occurring upon excess of certain filtration rates from bed to well.

The first criterion determines the upper mark of installation of water lifting equipment in the well, the second criterion determines the lower mark, thus, permissible installation area of water lifting equipment is determined.

The first operation condition of water lifting facility was estimated by the coefficient:

$$
k_{\text {cav }}=\frac{h_{w l . p e r m}-h_{w l}}{h}, 0 \leq h_{w l}<h_{w l . p e r m}, \begin{gathered}
1,0>h_{w l}, \\
-1, h_{w l} \geq h_{w l . p e r m}
\end{gathered}
$$

Possibility of suffosion was determined by the coefficient:

$$
k_{\text {cav }}=\frac{J-J_{\text {perm }}}{J} \quad \begin{aligned}
& 1, J \leq J_{\text {perm }} \\
& J>J_{\text {perm }}
\end{aligned}
$$

The optimum position variants of water lifting equipment in well were characterized by minimum functional values:

$$
\Phi=\int_{0}^{T} k_{c a v} d t+\int_{0}^{T} k_{s u f} d t
$$

The aforementioned main predictions are the basis of the developed model of water lifting system from water supply vacuum well using submersible pump; using this model, it has been established that installation of submersible pump with the device, which separates well shaft into the suction and injection areas, modifies operation pattern of the device, as upon conventional flowchart of water lifting after pump activation, the fluid level in annular space of casing string and water lifting pies is depressed to certain level considered as dynamic level. Then upon pipeless water lifting, depending on the pump installation depth, it is possible to operate without detachment of fluid from lower surface of the device, including rarefaction under the device, that is, the dynamic level, as such can be absent.

Increase in hydrodynamic resistance of well upon operation, for instance, as a consequence of filter colmatage, leads to the fact that the rarefaction generated by pump is completely consumed to override hydraulic resistances in the suction area 
and does not propagate into water bearing bed.

It has been established that when the submersible pump with the device is installed above the filter, it is impossible to achieve steady vacuuming of water bearing bed in imperfect well during long time due to increase in hydrodynamic resistance of well during operation, thus, in order to achieve steady vacuuming of water bearing bed, it would be reasonable to position the device above the filter, and the pump with shell - in the well sump.

When the pump with the device is located above the filter, the rarefaction under the device makes it possible to provide additional decrease in the head of underground waters in the well shaft, that is, to increase influx to the well, otherwise, using capability of submersible pump to operate with positive suction height, to compensate seasonal level variations of underground waters, to increase pump operation period when resources of underground waters are exhausted.

Simulation of water lifting system in transition mode for wells with open wellhead choke for various depths of pump submersion and level height demonstrates that for a pump installed tight into casing string, the cavitation-free operation of pump unit significantly depends on the distance between the device and the pump. Interdependence of the distance between pump and device is determined based on the condition of transient process without vacuum detachment in the area of pump suction.

Integrated consideration of pump operation in stationary and transient modes made it possible to highlight the areas of critical geometric height of suction for fixed values: coefficient of well resistance, water transmissivity and position of static level.

The following modes of pump operation are characteristic:

- $\quad$ steady vacuuming (hv $\geq 4 \mathrm{~m})$;

- $\quad$ unsteady vacuuming $(0 \leq \mathrm{hv} \leq 4 \mathrm{~m})$;

- $\quad$ operation with head or zero suction height $(0 \geq \mathrm{hv})$.

For new wells with $\xi=1$, the ETs V submersible pumps can operate at positive suction height of more than $6 \mathrm{~m}$ of water column.

The procedure of prediction of wells with pipeless installation of submersible pump is proposed. Special requirements, design and construction features of wells with pipeless installation of submersible pump are determined.

The wells for pipeless installation of submersible pumps are constructed by means of typical equipment and tools used in drilling practices. The scope and sequence of drilling operations are the same. Peculiar feature is comprised of sealed joining of casing pipes upon well arrangement to the depth of predicted installation of submersible pump.

The set of technological equipment for operation of wells with pipeless installation of submersible pumps was approved during commissioning tests.

Specifications of the device for pipeless water lifting from wells by submersible pumps, models UBV-8, UBV-10, UBV-12, UBV-14 were developed for fabrication of the equipment.

Kazakh Vodokanalproekt company included this device into typical project TP RK 1-12VS SKV-2009 "Water supply facilities from underground sources with the productivity from 1 to $12 \mathrm{~m}^{3} / \mathrm{h}$ ". 
Implementation of pipeless installation of submersible pumps at wells of irrigation, utility and agricultural water supply made it possible to determine details of operation, maintenance, monitoring of hydraulic parameters of water supply summarized in Operation manual.

The equipment for water evacuation through well casing string was applied at water supplies of Vodokanal enterprises in Alma-Ata, Aktobe, Uralsk, Kyzylorda, Taraz, Nalchik (Russia), Kant (Kirgizia), Tashkent, Gulistan (Uzbekistan), Zhetysu department of vertical drainage, Management department of Arys-Turkestan channel, Middle Irtysh Department of irrigation systems (Pavlodar), Aksupodzemvod(Taldykorgan), and some others. The mounted ETsVpumps operate in conformity with specifications.

The economic efficiency of pipeless mounting of submersible pump and sealing of mouth well is in saving of capital expenses for well equipment due to elimination of costs of water lifting pipes, the costs of their transportation and mounting; operation costs due to reduced labor intensity of mounting/dismounting operations during replacement or repair of pump and due to decrease in power consumption as a consequence of reduced head losses along the length of pressure pipeline.

Figure 18 illustrates devices for water evacuation through well casing string with the diameter of $219,273,324$, $377,426 \mathrm{~mm}$, characterized by the highest demand and having passed extended approbation.

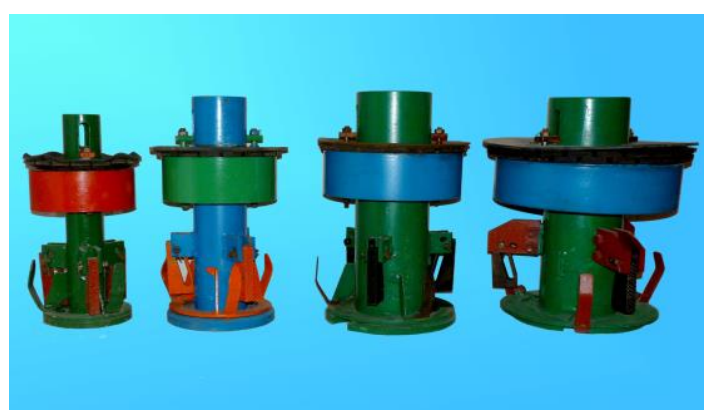

Figure 18: Device for Water Evacuation through Well Casing String with the Diameter of 219, 273, 324, 377, $426 \mathrm{~mm}$.

The systems of Vodokanal enterprise with installed pumps for evacuation of underground waters using the new technology have no claims by Sanepidemnadzor.

Technical and economical specifications of the device (Table 1) demonstrate its reasonability upon implementation of innovation projects.

The efficiency of the equipment for water evacuation through casing string only due to saving of water lifting pipes of one water supply well (at the cost of USD 770 per $1 \mathrm{t}$ of steel pipes) will equal from USD440to USD3,260.

Table 1: Efficiency of Technological Equipment for Evacuation of Underground Waters through Well Casing String with Accounting for Saving of Water Lifting Pipes

\begin{tabular}{|l|c|c|c|c|}
\hline $\begin{array}{c}\text { Model of } \\
\text { Submersible Pump }\end{array}$ & $\begin{array}{c}\text { Optimum Depth of } \\
\text { Installation in } \\
\text { Well, } \mathbf{m}\end{array}$ & $\begin{array}{c}\text { Diameter of Water } \\
\text { Lifting Pipe, mm }\end{array}$ & $\begin{array}{c}\text { Weight of } \\
\text { Pipes, kg }\end{array}$ & $\begin{array}{c}\text { Cost of saved Water Lifting } \\
\text { Pipes, USD }\end{array}$ \\
\hline ETsV6-10-110 & $85-130$ & $60 * 5$ & $576-881$ & $\mathbf{4 4 3 - 6 7 8}$ \\
\hline ETsV6-10-140 & $100-160$ & $60 * 5$ & $678-1,085$ & $\mathbf{5 2 2 - 8 3 6}$ \\
\hline ETsV8-16-140 & $120-160$ & $89 * 6,5$ & $1,752-2,336$ & $\mathbf{1 , 3 4 9 - 1 , 7 9 9}$ \\
\hline ETsV8-25-100 & $75-110$ & $89 * 6,5$ & $1,095-1,606$ & $\mathbf{8 4 3 - 1 , 2 3 7}$ \\
\hline ETsV10-63-110 & $90-130$ & $114 * 7$ & $1,662-2,401$ & $\mathbf{1 , 2 8 0 - 1 , 8 4 9}$ \\
\hline ETsV10-120-60 & $50-70$ & $114 * 7$ & $925-1,295$ & $\mathbf{7 1 2 - 9 9 7}$ \\
\hline
\end{tabular}




\begin{tabular}{|l|c|c|c|c|}
\hline ETsV12-160-65 & $50-80$ & $168 * 9$ & $1,765-2,824$ & $\mathbf{1 , 3 5 9 - 2 , 1 7 4}$ \\
\hline ETsV12-160-100 & $80-120$ & $168 * 9$ & $2,824-4,236$ & $\mathbf{2 , 1 7 4 - 3 , 2 6 2}$ \\
\hline
\end{tabular}

\section{CONCLUSIONS}

In terms of maximum economic efficiency, the optimum installation depth of ETsVpump with the device is as follows:

- for medium-head (60-70 m) pumps: $20 \ldots 40 \mathrm{~m}$;

- for high-head (100 $\mathrm{m}$ and above) pumps: $40 \ldots 80 \mathrm{~m}$.

In the case of pipeless installation of submersible pump, the metal intensity and total weight of the pump facility decrease by $60 \ldots 90 \%$, power consumption for delivery of fluid unit decreases by $10 \ldots 40 \%$, the possibility of pollution and infection of water horizons is eliminated, labor consumption of mounting/dismounting operations decreases by $40 \ldots 70 \%$.

More than 40 cities and towns in Kazakhstan receive water supply from 10 to 20 wells each; more than 2,000 rural settlements require for at least two water supply wells (working and spare); irrigation of pastures requires for more than 7,000 wells, excluding water supply wells used for irrigation and water supply for agroindustry and industrial enterprises.

Further development, if $50 \%$ of existing water supply wells are converted for operation according to the new technology, then the demand for the proposed equipment will be more than 5,000 sets. On the basis of the assumed demand, the annual implementation could be at least 500 sets.

\section{REFERENCES}

1. Trusov M. M., Fisenko V. N., and Rait V. Ya. Device for pipeless water extraction from wells. USSR Author certificate No.1633864. Byulleten' izobretenii, No. 48, 1988.

2. Tumlert V. A., Tumlert E. V., Rybintsev Yu. P., and Amangeldiev S. S. Device for evacuation of liquids from wells. KZ Patent 22926. Byulleten' Kazpatenta «Promyshlennaya sobstvennost'»No.9, 2010.

3. Tumlert V. A., Tumlert E. V., and Zhusip T. S. Device for evacuation of liquids from wells. KZPatent 26090.Byulleten' Kazpatenta «Promyshlennaya sobstvennost'»No.9, 2012.

4. Tumlert V.A. Tekhnologiya pod'ema vody po obsadnoi kolonne skvazhiny pogruzhnymi nasosami i ee effektivnost' [Water lifting through casing string by submersible pumps and its efficiency]. Vodnye resursy $i$ vodopol'zovanie, No.2(61), 2009, PP.25-28.

5. Kenenbaev T., Oroshenie zhdet kardinal'nykh mer [Irrigation requires for cardinal measures]. AgroZharshy, Nos. 18,19, 20, 2012.

6. BogolyubovK.S., GurinovichA.D., andZhelobovskiiA.G., Vodozabornaya vakuum-skvazhina [Watersupplyingvacuumwell], Vodosnabzhenie i sanitarnaya tekhnika, No.9,1987.

7. Grigor'evV.M., Vakkumnoe vodoponizhenie [Vacuumdewatering] (Stroiizdat, Moscow, 1973).

8. Gurinovich A.D., Gladkov V.D., Zhelobovskii A.G. Effektivnost' primeneniya ustroistv bestrubnoi podveski pogruzhnykh elektronasosov na vodozabornykh skvazhinakh [Efficiency of pipeless suspension of submersible electric pumps at water supply wells] (BelNIINTI, Minsk, 1979).

9. Gurinovich A. D. and Zhelobovskii A.G. Teoreticheskoe obosnovanie primeneniya bestrubnogo vodopod'ema [Theoretical substantiation of pipeless water lifting]. In: Puti sovershenstvovaniya proektirovaniya, stroitel'stva i ekspluatatsii ob'ektov 
sel'skokhozyaistvennogo naznacheniya [Ways of improvement of designing, construction, and operation of agricultural facilities] (Moscow, 1977).

10. Gurinovich A.D. and Zhelobovskii A.G. Bestrubnaya podveska pogruzhnykh nasosov na skvazhinakh [Pipeless suspension of submersible pumps at wells], Gidrotekhnika i melioratsiya», No.7, 1981.

11. Zhelobovskii A.G. Efficiency of water extraction and lifting through casing pipes. Synopsis, Can. thesis, Moscow, 1986.

12. TrusovM.M., FisenkoV.N., Gidravlicheskii raschet ustroistva bestrubnogo vodopod'ema $i$ effektivnost' ego primeneniya [Hydraulic analysis of pipeless water lifting and its efficiency]. Vestnik sel'skokhozyaistvennoi nauki Kazakhstana, No.2, 1987.

13. Usenko V.S., Zhelobovskii A.G., Intensifikatsiya otbora podzemnykh vod iz napornykh vodonosnykh gorizontov vakuumirovaniem skvazhin [Intensification of underground water withdrawal from pressure water horizons by well evacuation]. In: Kaptazh i ispol'zovanie podzemnykh vod [Groundwater tapping and use] (Moscow, 1983).

14. M. M. Trusov, V. N. Fisenko, and V. Ya. Rait. Pipeless device for water lifting from wells. USSR Author certificate No.1633864. Byul.No.23, 1988.

15. Tumlert V. A., Tumlert E. V., Rybintsev Yu. P., and Amangeldiev S.S. Device for evacuation of liquids from wells. KZ Patent No.22926.Byul.No.9, 2010.

16. Tumlert V.A., Rybintsev Yu.P., and Grankin Yu.Ya. Device for liquid evacuation from well. KZ Patent No. 24313. Byul. No. 8, 2011.

17. Tumlert V. A., Tumlert E. V., and Zhusip T.S. Device for liquid evacuation from well. KZ Patent No. 26090. Byul. No. 9, 2012.

18. V. A. Tumlert, E. V. Tumlert, T. Sh. Ustabaev, I. A. Yugai, and B. D.Ismailov. Tekhnologiya vodopod'ema iz skvazhin s bestrubnoi ustanovkoi nasosa [Water lifting from wells with pipeless installation of pump] Naukai Mir No. 122016.

19. Tumlert V. A., Yugai I. A., Tel'garaeva G. E., and Tumlert E. V. Vnedrenie novoi resurso-sberegayushchei tekhnologii ekspluatatsii skvazhin vertikal'nogo drenazha na oroshaemykh massivakh Yuzhno-Kazakhstanskoi oblasti [Implementation of new resource-saving operation of vertical drainage wells in irrigated areas of South Kazakhstan], Minsk, October, 2016.

20. Dobrota L. Ostanovim zasolenie zemel' [Soil salinization should be terminated]. Kazakhstanskaya pravda, December 3, 2009.

21. Rekomendatsii po upravleniyu meliorativnymi rezhimami na oroshaemykh zemlyakh [Recommendations on management of melioration modes at irrigated areas]. / F.F.Vyshpol'skii, S.D.Magai, and K. T. Raimbaev (Taraz, 1998).

22. Magai S.D. Metodika ekologo-meliorativnogo obosnovaniya drenazhnykh sistem na oroshaemykh zemlyakh [Procedure of environmental substantiation of draining systems at irrigated lands]. Trudy KazNIIVKh. - Taraz, 1999, PP.64-76. 